\title{
CHEMICAL AND MICROBIOLOGICAL PROPERTIES OF BUDUK, A COMMERCIAL FISH SAUCE FROM WEST KALIMANTAN
}

\author{
Risa Nofiani*, Endang Elminah, Puji Ardiningsih \\ Department of Chemistry, Mathematics and Natural Sciences Faculty, Tanjungpura University, \\ Prof. Dr. H. Hadari Nawawi Street, Pontianak, Indonesia 78124. Telephone/Facsimile.: (561)577963 \\ ${ }^{*}$ Corresponding author:risa.nofiani@chemistry.untan.ac.id \\ Accepted: 14 May 2019/ Approved: 18 December 2019
}

How to cite: Nofiani R, Elminah E, Ardiningsih P. 2019. Chemical and microbiological properties of buduk, a commercial fish sauce from West Kalimantan. Jurnal Pengolahan Hasil Perikanan Indonesia. 22(3): 601608.

\begin{abstract}
Buduk is a fish sauce prepared by fermenting fresh small fish with various ingredients such as sugar, roasted rice, vinegar or wine. This study was aimed to assess the physicochemical and microbiological properties of commercial buduk in the Province of West Kalimantan. The Buduk had pH 5-55, moisture $52.35 \%$, salt $1.96 \%$, titrated acid $10.80 \%$, free amino nitrogen $1.83 \mathrm{mmol} / \mathrm{g}$, free fatty acid $17.96 \%$, ethanol $0.95 \%$, total of mesophilic bacteria $4.81 \mathrm{log}$ CFU/g and lactic acid bacteria $2.09 \mathrm{CFU} / \mathrm{g}$, but no pathogenic bacteria detected. Each commercial buduk showed different physicochemical properties probably caused by variation in recipe of each producer. The microbiological properties did not significantly different but the TMAB found more than the threshold value indicating each producer needs to improve hygienical buduk processing to improve the quality of buduk.
\end{abstract}

Keywords: anchovies, buduk, fermentation, fish sauce

\section{Sifat Fisikokimia dan Mikrobiologi Buduk, Saus Ikan Komersial dari Kalimantan Barat}

\begin{abstract}
Abstrak
Buduk adalah saus ikan yang dibuat melalui fermentasi ikan-ikan kecil yang segar dengan bermacam-macam bahan tambahan seperti: gula, beras yang sudah disangrai, cuka atau arak. Studi ini bertujuan untuk menilai sifat fisikokimia dan mikrobiologi komersial buduk yang beredar di pasaran Provinsi Kalimantan Barat. Sifat fisikokimia dan mikrobiologi ditentukan. Komersial buduk di Provinsi Kalimantan Barat memiliki pH 5,5, kelembaban 52,35 \%, garam 1,96 \%, keasaman yang bisa dititrasi 10,80\%, nitrogen amino bebas 1,83 mmol/g, ALB 17,96 \%, etanol 0,95\%, ALT 4,81 log CFU/g, BAL 2,09 $\log C F U$ dan tidak terdeteksi adanya bakteri patogen. Umumnya komersial buduk menunjukkan perbedaan signifikan sifat-sifat fisikokimia yang mungkin disebabkan oleh resep tiap produser yang digunakan berbeda. Sifat-sifat mikrobiologi komersial buduk menujukkan tidak berbeda signifikan tetapi jumlah ALT yang melebihi nilai ambang batas mengindikasikan bahwa tiap producer memerlukan pengetahuan yang baik tentang cara-cara produksi yang higinis untuk meningkatkan kualitas buduk komersial.
\end{abstract}

Kata Kunci: buduk, fermentasi, ikan teri,saus ikan

\section{INTRODUCTION}

Buduk is a traditional and spontaneous fermentation food and categorized as a fish sauces which can be found in West Kalimantan. Buduk is prepared by fermenting fresh small fish with various ingredients such as sugar, roasted rice, vinegar, or wine. Buduk is usually consumed with rice by the community of West Kalimantan. Buduk contributes significantly to the diet, particularly increasing protein intake. Fish sauce and fish paste is very common in South-East Asia and known with different names and the recipes as well as the processings. Beside buduk, other fish sauce 
have been reported by some researchers such as budu from West Sumatera (Huda and Rosma, 2006) and Malaysia (Nadiah et al. 2014). The budu from West Sumatra is made from big size marine fish such as Scomberomorus sp. (Spanish Mackerel) or Chorinemus sp. (Huda and Rosma 2006). The Malaysian budu, a dark brown liquid, is made from anchovies (Stolephorus sp./bilis fish, Sardinella sp., Decaterus macrosoma) as the raw material. The anchovies were mixed with salt in the ratio 3:2 then fermented for 6-12 months (Ray and Montet 2015). However, the Malaysian budu and The Province of West Kalimantan of buduk are different in their production or product appearance. Rusip, the other fish sauce of Bangka Island (East Sumatera), Indonesia, uses anchovies (Stolephorus sp.) mixed with salt and palm sugar and kept for two weeks (Nadiah et al. 2014). Toeuktrey, a Cambodian fish sauce, uses freshwater fishes and is incubated for less than a month and several months (Chuon et al. 2014). Jeotgal, a fermented fish sauce of Korea, is made from sea animals (whole fish, fish roe, internal organs of fish and shellfish) and high salt (20-30\% [w/w]) (Jung et al. 2018). Bakasang, a fermented fish sauce of Indonesia is made from small fish (sardine, Engraulis japonicus) (Ijong and Ohta 1996)

Spontaneous fermentations utilize natural microorganisms contained in the raw material as a starter to trigger protease production during fermentation. The natural microorganisms help converting protein of fish flesh to simple peptides. The freshness of raw material contributes to the protein quality of fish sauce (Nadiah et al. 2014). Each raw material contains certain microorganisms causing a high variation of the buduk quality or inconsistency in the products, which can be assessed by chemical and microbiological properties. The buduk quality also depends on the freshness of anchovies, the recipe, and the condition during buduk processing. This study was aimed to determine the chemical and microbiological characteristics of commercial buduk from West Kalimantan.

\section{MATERIALS AND METHODS Materials}

The chemical reagents for chemical analysis were formaldehyde (Merck), $\mathrm{NaOH}$ (Merck), phenolphthalein (Merck), $\mathrm{K}_{2} \mathrm{CrO}_{4}$ (Merck), $\mathrm{AgNO}_{3}$ (Merck), $\mathrm{NaCl}$ (Merck), $\mathrm{KI}$ (Merck), $\mathrm{H}_{2} \mathrm{SO}_{4}$ (Merck), $\mathrm{Na}_{2} \mathrm{~S}_{2} \mathrm{O}_{3}$ (Merck), $\mathrm{HCl}$ (Merck), $\mathrm{K}_{2} \mathrm{Cr}_{2} \mathrm{O}_{7}$ (Merck), and Starch (Difco), The microbiological reagents used in this research were Plate Count Agar/ PCA (Difco), Oxytetracycline Glucose-Yeast Extract Agar/OGYE (Oxoid), de Man, Rogosa and Sharpe agar/MRSA (Scharlau 01-135), Mannitol Egg Yolk Polymyxin agar/MYPA (Oxoid), Tryptose Sulfite Cycloserine Agar/ TSCA (Himedia), Violet Red Bile Glucose Agar/VRBGA (Scharlau 01-295), Mannitol Salt Phenol Red Agar/MSPRA (Merck's 1.05404.0500), and McBride Listeria Agar Base/MLAB (Fluka 62355). The equipment used in this research were $\mathrm{pH}$-Meter (Contech, India), balance (Ohaus, USA), Laminar flow (Sterimac, India), and oven (Vinci, France)

\section{Sampling}

Commercial buduk was bought randomly from various traditional market in West Kalimantan including: Pontianak, Singkawang, Mempawah, Sambas, and Kuburaya.

\section{Methods \\ Chemical Analysis Preparation of samples}

Each sample was prepared by homogenization using a hand blender. The homogenate was analysed for their chemical and proximate compositions. The homogenate was stored at $4^{\circ} \mathrm{C}$ before use.

\section{pH}

One g of homogenate was diluted with nine $\mathrm{mL}$ of distilled water. Then, the mixture was stirred using a glass stirring rod. The $\mathrm{pH}$ of the mixture was measured using digital $\mathrm{pH}-$ meter.

\section{Free amino nitrogen (FAN)}

Free amino nitrogen (FAN) was analyzed based on the formol titration (Northrop 1926; Lee et al. 2016). Two grams of homogenated 
sample were diluted with $18 \mathrm{~mL}$ of distilled water. After addition of $5 \mathrm{~mL}$ of $37 \%$ formaldehyde, the sample was titrated with $0.1 \mathrm{M} \mathrm{NaOH}$ until $\mathrm{pH}$ to be 8.5 , which should be constant for $30 \mathrm{~s}$. The FAN was measured as follow:

$\mathrm{FAN}=\frac{\mathrm{M} \mathrm{NaOH} \times \mathrm{V} \mathrm{NaOH}}{\text { Mass of sample }(\mathrm{g})}$

\section{Titratable acidity}

Titratable acidity was determined based on acid-base titration. Five $\mathrm{g}$ of homogenated sample were centrifugated at $4.000 \mathrm{x}$ g for 30 min to generate supernatant. Five $\mathrm{mL}$ of the supernatant were diluted with $10 \mathrm{~mL}$ of boiled water. After cold, the mixture was added with five drops of phenolphthalein indicator and subsequently titrated with $\mathrm{NaOH} 0.1 \mathrm{M}$. The titratable acidity was measured as follow:

Titratable acidity $=\frac{\mathrm{M} \mathrm{NaOH} \times \mathrm{V} \mathrm{NaOH} \times 0.9}{\text { V sample }} \times 100 \%$

\section{Ethanol content}

Ethanol content was determined using reduction-oxidation titration. A small vial containing two $\mathrm{g}$ of sample was hung to a rubber stopper which used to cover a conical flask containing $10 \mathrm{ml}$ of acid dichromate $(0.01$ $\mathrm{M} \mathrm{K}_{2} \mathrm{Cr}_{2} \mathrm{O}_{4}$ in $\mathrm{H}_{2} \mathrm{SO}_{4} 5 \mathrm{M}$ ). After incubation at $30^{\circ} \mathrm{C}$ for 24 hours, the acid dichromate was added with two-three drops of KI 10\% and titrated with $\mathrm{Na}_{2} \mathrm{~S}_{2} \mathrm{O}_{7} 0.03 \mathrm{M}$ until yellow. This solution then added with two-three drops of amylum $1 \%$ and re-titrated with $\mathrm{Na}_{2} \mathrm{~S}_{2} \mathrm{O}_{7} 0.03$ $\mathrm{M}$ until slightly blue. Percentage of ethanol was calculated as follow:

$\%$ Ethanol $=\frac{\text { Mass of ethanol }(\mathrm{g})}{\text { Mass of sample }(\mathrm{g})} \times 100 \%$

\section{Salt content}

Salt content was determined based on Mohr method. Five $\mathrm{mL}$ of supernatant (titratable acidity procedure) were diluted with $45 \mathrm{~mL}$ of aquadest. Two drops of $10 \%$ of $\mathrm{K}_{2} \mathrm{CrO}_{4}$ was added and the solution then was titrated with $0.1 \mathrm{AgNO}_{3} \mathrm{M}$ until white precipitation formed. Salt content was calculated as follow:

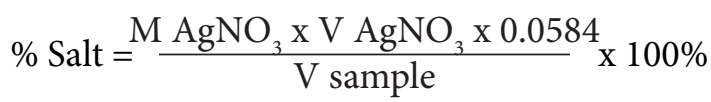

\section{Free fatty acid (FFA)}

Five hundreds milligram of homogenated sample was mixed with $5 \mathrm{~mL}$ of ethanol (95\%) then heated at $70^{\circ} \mathrm{C}$. Two drops of phenolphthalein was added into the solution. The sample was titrated with $\mathrm{NaOH} 0.1 \mathrm{M}$ until pale pink colour. The FFA was reckoned using formula as follow:

$\% \mathrm{FFA}=\frac{\mathrm{M} \mathrm{NaOH} \times \mathrm{V} \mathrm{NAOH} \times 282}{\text { Mass of sample }(\mathrm{g}) \times 10} \times 100 \%$

\section{Microbiological analysis}

Five grams of each buduk sample were suspended in $45 \mathrm{~mL}$ of saline buffer $(0.9 \%$ of $\mathrm{NaCl}$ solution). The suspension sample was used for microbiological analysis.

Total of Mesophilic Aerobic Bacteria (TMAB) was determined using a serial dilution of the suspension sample $\left(10^{-1}, 10^{-2}\right.$, $10^{-3}, 10^{-4}, 10^{-5}$ and $\left.10^{-6}\right)$ inoculated on plate count agar (PCA) medium and incubated at 37 ${ }^{\circ} \mathrm{C}$. After 48 hours, the mounted of TMAB was calculated by following formula $=$ the number of colony $\mathrm{x}$ dillution factor. Each colony appeared in the medium surface was counted as colony forming unit (CFU) of TMAB.

Five microliters of the suspension sample was inoculated into Mannitol Egg Yolk Polymyxin Agar (MYPA) supplemented with $15 \mathrm{~g} / \mathrm{L}$ of $\mathrm{NaCl}$, Violet Red Bile Dextrose Agar (VRBD) supplemented with $\mathrm{NaCl} 15 \mathrm{~g} / \mathrm{L}$ and Mannitol Salt Agar (MSA) supplemented with $15 \mathrm{~g} / \mathrm{L}$ of $\mathrm{NaCl}$ and incubated at $37{ }^{\circ} \mathrm{C}$ for 3 days. A positive colony of Bacillus cereus, Enterobacteriaceae, and Staphylococcus aureus were identified with a pink colony on MYPA, a pink colony on VRBG, and golden yellow colony on MSA. Each positive colony was further confirmed using morphological and biochemical tests based on Bergey's Manual of Determinative Bacteriology

(Holt et al. 1994). Clostridium perfringens and Listeria monocytogenes were detected by inoculating the suspension sample $(5 \mu \mathrm{L})$ in selective media Tryptose Sulfite Cycloserin Agar (TSCA) enriched with $\mathrm{NaCl} 15 \mathrm{~g} / \mathrm{L}$ 
and Listeria Salt Agar (LSA) enriched with $15 \mathrm{~g} / \mathrm{L}$ of $\mathrm{NaCl}$, respectively. After incubation at $37{ }^{\circ} \mathrm{C}$ for 24 hours, a black and yellow colony were predicted as $C$. perfringens and L. monocytogenes, respectively then further confirmed based on Bergey's Manual of Determinative Bacteriology (Holt et al. 1994).

Five microlitres of the suspension sample was inoculated into MRS agar supplemented with $\mathrm{CaCO}_{3} 1 \%$ and incubated anaerobically at $30{ }^{\circ} \mathrm{C}$ for three days. A clear zone around colonies was suspected as Lactic Acid Bacteria (LABs). The LABs was confirmed using morphological and biochemical tests according to Bergey's Manual of Determinative Bacteriology (Holt et al. 1994).

The sample was inoculated into Potatoes Dextrose Agar (PDA) medium enriched with $15 \mathrm{~g} / \mathrm{L}$ of $\mathrm{NaCl}$ and incubated at $30^{\circ} \mathrm{C}$. After five days, each fungal colony was counted as colony forming units (CFU) per gram wet weight of samples.

\section{Statistical analysis}

All of the experimental data were grouped into blocks based on a randomized complete block design approach. All of the data were presented as mean \pm standard deviation, and the variance between the group was analyzed using an LSD with $95 \%(\mathrm{p}<0.05)$ confidence level. The $\mathrm{IBM}^{\otimes}$ Statistics 23 was used for the data analysis.

\section{RESULTS AND DISCUSSION Sampling}

Buduk is a favorite meal in Province of West Kalimantan, particularly people who live

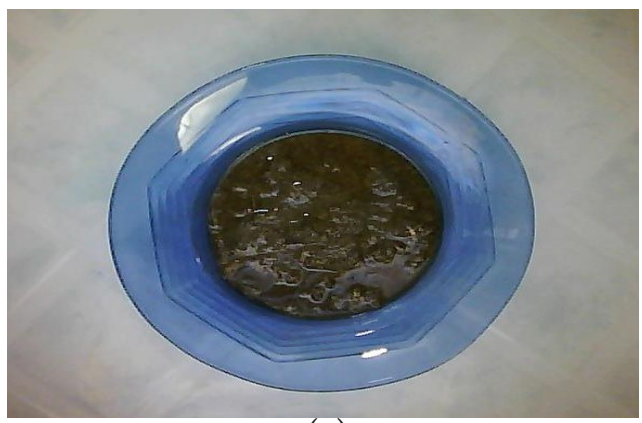

(a) along the coast (Figure 1a). We focused on collecting samples from municipality/regency close with the coast or the islands which are probably to be the primary producers of the buduk in West Kalimantan such as Pontianak, Singkawang, Pontianak, Sambas, and Kuburaya.

The raw material of buduk is small fish with low selling price such as white or black anchovies (Stolephorus indicus), seluang fish (Rasbora dusonensis), and small other fish. However, Stolephorus indicus is the common raw material to make buduk in West Kalimantan particularly Temajo Island dan Kabung Island (Figure 1b). The other materials in buduk production are salt, sugar, roasted rice or cooked rice, vinegar or wine. Different raw materials is used in the buduk production affect the quality of the product mainly taste, flavour, aroma and nutrition.

The physicochemical profile of the buduk was significantly different $(\mathrm{p}<0.05)$ for all of the sample except the ethanol content (Table $1)$. The moisture of buduk (52.35 $\pm 5.975 \%)$ was lower than that of budu (67\%), rusip $(65 \%)$, cincalok $(67 \%)$, or ale-ale $(60 \%)$ (Nadiah et al. 2014; Nofiani and Ardiningsih 2018; Nofiani et al. 2010). It is thought that salt content and fermentation time affect the moisture in fermentation.

\section{Chemical analysis}

The physicochemical profile of the buduk was significantly different $(\mathrm{p}<0.05)$ for all of the sample except the ethanol content (Table 1 ). The moisture of buduk (52.35 $\pm 5.97 \%)$ was lower than that of budu (67\%), rusip (65\%),

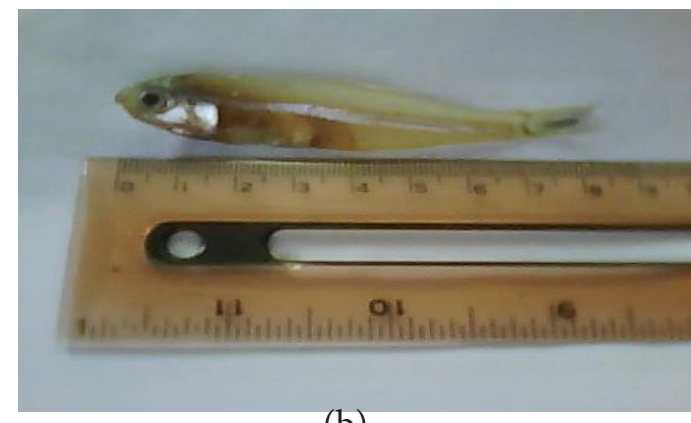

(b)

Figure 1 (a) Sample of commercial buduk (b) Stolephorus indicus as the primary material to make Buduk 
Table 1 Chemical properties of the buduk

\begin{tabular}{cccccccc}
\hline $\begin{array}{c}\text { Location of } \\
\text { producer }\end{array}$ & $\mathrm{pH}$ & $\begin{array}{c}\text { Moisture } \\
(\% \mathrm{w} / \mathrm{v})\end{array}$ & $\begin{array}{c}\text { Salt } \\
(\% \mathrm{w} / \mathrm{v})\end{array}$ & $\begin{array}{c}\text { Titrable } \\
\text { acidity } \\
(\% \mathrm{w} / \mathrm{v})\end{array}$ & $\begin{array}{c}\text { FAN } \\
(\mathrm{mmol} / \mathrm{g})\end{array}$ & $\begin{array}{c}\text { Ethanol } \\
(\% \mathrm{w} / \mathrm{w})\end{array}$ & $\begin{array}{c}\text { FFA } \\
(\% \mathrm{w} / \mathrm{w} \\
\text { as oleic })\end{array}$ \\
\hline Pontianak & $5.67 \pm 0.53^{\mathrm{a}}$ & $55.05 \pm 2.87^{\mathrm{a}}$ & $2.04 \pm 0.09^{\mathrm{a}}$ & $11.26 \pm 0.30^{\mathrm{a}}$ & $2.16 \pm 0.04^{\mathrm{a}}$ & $0.93 \pm 0,03^{\mathrm{a}}$ & $17.96 \pm 0.52^{\mathrm{a}}$ \\
Singkawang & $5.42 \pm 0.05^{\mathrm{ac}}$ & $54.66 \pm 2.43^{\mathrm{a}}$ & $1.61 \pm 0.42^{\mathrm{bc}}$ & $9.89 \pm 0.09^{\mathrm{b}}$ & $1.56 \pm 0.48^{\mathrm{b}}$ & $0.95 \pm 0.05^{\mathrm{a}}$ & $21.71 \pm 4.34^{\mathrm{b}}$ \\
Sambas & $5.27 \pm 0.07^{\mathrm{bc}}$ & $48.49 \pm 6.81^{\mathrm{b}}$ & $2.03 \pm 0.12^{\mathrm{ad}}$ & $10.45 \pm 0.32^{\mathrm{c}}$ & $1.93 \pm 0.11^{\mathrm{a}}$ & $0,96 \pm 0.02^{\mathrm{a}}$ & $21.37 \pm 2.86^{\mathrm{b}}$ \\
Kuburaya & $5.98 \pm 0.11^{\mathrm{ac}}$ & $52.66 \pm 5.03^{\mathrm{a}}$ & $2.20 \pm 0.01^{\mathrm{ae}}$ & $13.37 \pm 0.04^{\mathrm{d}}$ & $1.53 \pm 0.15^{\mathrm{b}}$ & $0,96 \pm 0.03^{\mathrm{a}}$ & $20.96 \pm 0.49^{\mathrm{ab}}$ \\
Mempawah & $5.76 \pm 0.46^{\mathrm{acd}}$ & $52.97 \pm 8.11^{\mathrm{a}}$ & $2.00 \pm 0.25^{\mathrm{af}}$ & $10.48 \pm 0.64^{\mathrm{ce}}$ & $1.58 \pm 0.25^{\mathrm{b}}$ & $0,92 \pm 0.08^{\mathrm{a}}$ & $21.41 \pm 0.59^{\mathrm{b}}$ \\
Average & $5.55 \pm 0.38$ & $52.35 \pm 5.97$ & $1.96 \pm 0.28$ & $10.80 \pm 1.04$ & $1.83 \pm 0.33$ & $0.95 \pm 0.05$ & $20.72 \pm 2.76$ \\
\hline
\end{tabular}

Information: The different letter in the same column assigns significantly different $(\mathrm{P}<0.05) . \mathrm{n}=11 . \mathrm{r}=3$

cincalok (67\%), or ale-ale (60\%) (Nadiah et al. 2014; Nofiani and Ardiningsih 2018; Nofiani et al. 2010). It is thought that salt content and fermentation time affect the moisture in fermentation.

$\mathrm{pH}$ value is used to determine proton dissociated from organic acids during fermentation such as acetic acid or formic acid. Organic acids are produced as a result of lactic acid bacterial activities. The proton of the organic acids causes decrease in $\mathrm{pH}$ of fermentation products, giving an effect toward the microorganism profile of fermentation. Therefore, $\mathrm{pH}$ can be used as an indicator to determine the quality of the fermentation product.

The $\mathrm{pH}$ value in fermentation products can be increased by extending the fermentation time, as a result of, for example, ammonia production (Anggo et al., 2015). The average $\mathrm{pH}$ of the commercial buduk was $5.55 \pm 0.38$ (Table 1). Some of the fermented fish from West Kalimantan have similar $\mathrm{pH}$ value such as fermented ale-ale and cincalok (Nofiani et al. 2010; Nofiani and Ardiningsih 2018). The $\mathrm{pH}$ of the fish paste produced from the Province of West Java was higher than that of the buduk which is 6.42 (Anggo et al. 2015). Traditional bakasang shows $\mathrm{pH}$ value from 5.95 to 6.55 (Ijong and Ohta 1996). The $\mathrm{pH}$ of budu (5.17) and rusip (4.98) from Malaysia is lower than that of buduk (Nadiah et al. 2014).

Titratable Acidity (TA) was also measured in this study, to determine the total concentration of free proton and undissociated acids, which can react with a strong base. In this study, high TA values was not followed by low $\mathrm{pH}$ values. Therefore, the $\mathrm{pH}$ and $\mathrm{TA}$ values did not show a positive correlation (Table 1). For example, the TA of Pontianak is 11.26, higher than that of Mempawah, but the $\mathrm{pH}$ of Pontianak was lower than that of Mempawah (Table 1). The TA of buduk was in average $10.80 \pm 1.04 \% \mathrm{w} / \mathrm{v}$ (Table 1). This value was probably produced as a result of $\mathrm{LAB}$ activities that convert carbohydrate to lactic acid, propionic bacteria, butyric acid, and acetic acid (Elferink et al. 2001; Pessione 2012).

Salt is pivotal ingredient to adjust microorganism profile involved in fermentation. For example, salt with a certain concentration can inhibit the growth of some spoilage and pathogenic bacteria. In addition, salt contributes to decreasing water activity of substrate by increasing substrate osmosis pressure which reduces water from the substrate. As a result, the only specific microorganism can ferment the substrate. High salt concentration can inhibit proteolytic enzymatic activity contained in substrate and $\mathrm{LAB}$ activity. However, the salt value of buduk was categorized as low salt, which did not likely inhibit the LAB growth. The salt value did not significantly different among each district except for Singkawang. This salt value is similar to that of fermented ale-ale but lower than that of other fermented food such as cincalok, Bangka buduk (17-30\%) and Malaysian budu (21.50-25.70 \% (w/v) (Rosma et al. 2009; Nofiani and Ardiningsih 2018; El Sheikha and Montet 2015).

The free amino nitrogen (FAN) in the fermentation is used to determine the degradation level of protein by microorganism proteolytic activities, which are counted as 
Table 2. Microbiological Properties of Commercial Buduk

\begin{tabular}{cccccc}
\hline \multirow{2}{*}{ Microorganism } & \multicolumn{4}{c}{ Total Log CFU/g of Block Samples } \\
\cline { 2 - 5 } & Pontianak & Singkawang & Sambas & Kuburaya & Mempawah \\
\hline TMABs & $5.06 \pm$ & $4.99 \pm 0.39^{\mathrm{a}}$ & $5.03 \pm$ & $4.34 \pm 0.23^{\mathrm{a}}$ & $4.51 \pm 0.15^{\mathrm{a}}$ \\
& $0.32^{\mathrm{a}}$ & & $0.55^{\mathrm{a}}$ & & \\
LABs & $2.00 \pm$ & $2.06 \pm 2.9^{1 \mathrm{a}}$ & $1.00 \pm$ & $4.08 \pm 0.01^{\mathrm{a}}$ & $1.85 \pm 2.62^{\mathrm{a}}$ \\
& $2.83^{\mathrm{a}}$ & & $1.73^{\mathrm{a}}$ & & \\
Fungi & n.d. & n.d. & n.d. & n.d. & n.d. \\
Pathogenic Bacteria & n.d. & n.d. & n.d. & n.d. & n.d. \\
\hline Thermation: Pathogenic bacteria: B. cereus, C.perfringens, Enterobacteriaceae, S. aureus, and L. monocytogenes. \\
The sameletter in the same row assigns no significantly different $(P<0.05) . \mathrm{n}=11 . \mathrm{r}=3$
\end{tabular}

amino acids, small peptides, and ammonium ion. High levels of FAN contribute to the rise of $\mathrm{pH}$. The FAN of buduk in this study was in average of $1.83 \pm 0.33 \mathrm{mmol} / \mathrm{g}$ (Table 1 ) which is higher than the FAN of fermented aleale and cincalok from the Province of West Kalimantan (Nofiani et al. 2010; Nofiani and Ardiningsih 2018).

Buduk in this study contained ethanol with ranged from 0.92 to $0.96 \%(b / b)$, which did not significantly different among samples (Tabel 1). The ethanol was produced by the LAB and the TMAB activities. The LABs are able to convert pulp substrate into ethanol, lactic acid, and acetic acid (Anal 2019). Ethanol and organic acids contribute to developing specific taste and flavor attributes (Chiang and Ismail 2006; Ayad et al. 2001; Ines and Falco 2019).

Free fatty acids (FFA) are product of lipase and phospholipase activities (Gandemer 2002). It can be used to develop flavor compounds of fermented products and as indicators of product quality such as spoilage and rancidity (Xu et al. 2019). The FFA of buduk showed range from $17.96 \%$ to $21.41 \%$ (Table 1 ).

This suspect colony showed Grampositive with coccus form using Gram staining. The suspect colony also positive to ferment glucose, lactose, maltose, and sucrose, but not mannitol. The suspect colony possessed catalase and oxidase-negative and motile. On the basis of the morphological and biochemical tests, the suspect colony was identified as Streptococcus sp. Streptococcus sp. has been used to ferment milk to produce kefir and Streptococcus thermophilus was applied to produce yoghurt (García et al. 2019).

\section{Microbiological analysis}

Microorganisms are pivotal to improve the flavor and taste. Microorganisms such as lactic acid bacteria (LABs), Micrococcus, and yeast are involved in food fermentation (Wu et al. 2015). The buduk samples in this study contained TMAB and LABs but no fungi and pathogenic bacteria (Table 2).

The TMAB value can be used to describe the product quality, contamination, expiry date, and hygienic status but no relation to product safety. The TMABs of all samples were higher than the threshold value $(<1$ Log CFU/g allowed by Indonesian National Standard (SNI)7388:2009 (Table 2).

LABs are desirable bacteria in fish fermentation, particularly to inhibit microbial spoilage by competiting them, developing toxins, enhance flavor and reduce pathogenic microorganisms (Rhee et al. 2011; Glatman et al. 2000; Sedanza et al. 2016; $\mathrm{Xu}$ et al. 2019). The positive colony LABs were identified by a clear zone around colony (Figure 2). A clear zone around the colony was isolated then identified based on Bergey's Manual of Determinative Bacteriology (Holt et al. 1994). The LAB and TMAB collony members of all buduk analyzed similar (Table $1)$.

\section{CONCLUSION}

The commercial buduk samples in this study showed a significant difference in the chemical properties except for ethanol content. However, all of the commercial buduk samples exhibited an insignificant difference in the microbiological properties. As a result, the 


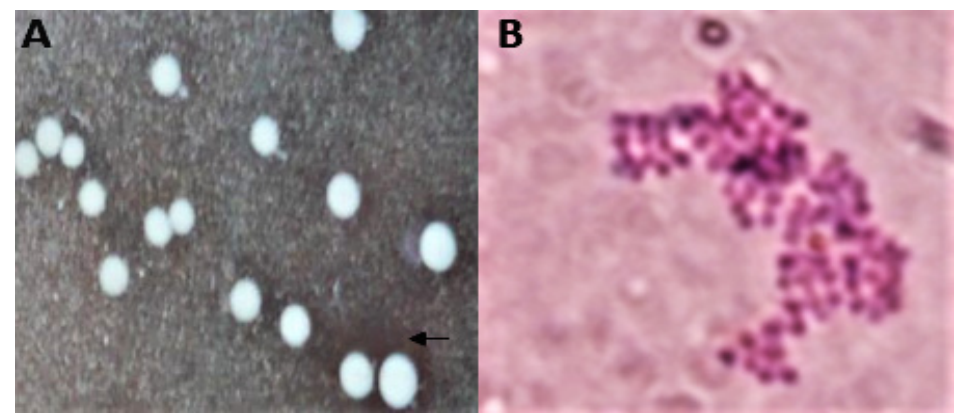

Figure 2. A. clear zone around LAB colonies (arrow) on MRS medium supplemented with $\mathrm{CaCO}_{3} ; \mathrm{B}$. The LAB takes the form of a Gram-positive cocci

quality of commercial buduk in the market of West Kalimantan Province is different for each producer. The fungi and pathogenic bacteria were not detected in the commercial buduk, but the TMABs exceeds the value threshold permitted by Indonesian National Standard. On the basis of TMAB value, each producer needs to improve knowledge on the hygiene to increase the buduk quality.

\section{ACKNOWLEDGMENTS}

We thank Directorate General of Higher Education, Ministry of Education and Culture funded this project through Young Lecturer Research Grant.

\section{REFERENCES}

Anal AK, 2019. Quality Ingredients and Safety Concerns for Traditional Fermented Foods and Beverages from Asia: A Review. Fermentation. 5(1), 8-20.

Anggo AD, Ma WF, Swastawati F, Rianingsih L. 2015. Changes of Amino And Fatty Acids In Anchovy (Stolephorus sp. ) Fermented Fish Paste With Different. Procedia Environmental Sciences. 23:5863.

Ayad EHE, Verheul A, Engels WJM, Wouters JTM, Smit G. 2001. Enhanced Flavour Formation by Combination of Selected Lactococci from Industrial and Artisanal Origin with Focus on Completion of a Metabolic Pathway. Journal of Applied Microbiology. 90:59-67.

Chiang YW, Ismail M. 2006. Microbial Diversity and Proximate Composition of Tapai, A Sabah's Fermented Beverage. Malaysian Journal of Microbiology.
2(1):1-6.

Chuon MR, Shiomoto M, Koyanagi T, Sasaki T, Michihata T, Chan S, Mao S, Enomoto, T. 2014. Microbial and chemical properties of Cambodian traditional fermented fish products. Journal of the Science of Food and Agriculture. 94(6):1124-1131.

Elferink JWHO, Krooneman J, Gottschal JC, Spoelstra SF, Faber F, Driehuis F. 2001. Anaerobic Conversion of Lactic Acid to Acetic Acid and 1, 2-Propanediol by Lactobacillus buchneri. Applied and Environmental Microbiology. 67(1):125132.

El Sheikha AF, Montet D. 2015. Fermented Fish and Fish Products: Snapshots on Culture and Health in Ray RC, Montet. (Editors). Microorganisms and Fermentation of Traditional Foods. New York (US): Published by CRC Press Taylor and Francis Group.

Gandemer G. 2002. Lipids in Muscles and Adipose Tissues, Changes during Processing and Sensory Properties of Meat Products. Meat Science. 62:309-321.

García C, Rendueles M, Díaz M. 2019. LiquidPhase Food Fermentations with Microbial Consortia Involving Lactic Acid Bacteria. Food Research International. 119:207220.

Glatman L, Drabkin V, Gelman A. 2000. Using Lactic Acid Bacteria for Developing Novel Fish Food Products. Journal of the Science of Food and Agriculture. 380:375-380.

Holt J, Krieg N, Sneath P, Staley J, Williams S. 1994. Bergey's Manual of Determinative Bacteriology. 9th Edition . Baltimore (US): Published by William and Wilkins. 
Huda N, Rosma A. 2006. Budu and Tukai: Endemic fermented fish products from West Sumatra. Infofish International. 3:49-51.

Ijong FG, Ohta Y. 1996. Physicochemical and Microbiological Changes Associated with Bakasang Processing-A Traditional Indonesian Fermented Fish Sauce. Journal of Science Food Agricultural. 71:69-74.

Ines A, Falco V. 2019. Lactic Acid Bacteria Contribution to Wine Quality and Safety. In Generation of Aroma and Flavours. London (UK):Published by IntechOpen.

Jung MY, Kim TW, Lee C, Kim JY, Song HS, Kim YB, Ahn SW, Kim JS, Lee SH. 2018. Role of jeotgal, a Korean Traditional Fermented Fish Sauce, in Microbial Dynamics and Metabolite Profiles during Kimchi Fermentation. Food Chemistry. 265:135-143.

Lee H, Choi Y, Hwang IM, Hong SW, Lee M. 2016. Relationship Between Chemical Characteristics and BacterialCommunity of A Korean Salted-Fermented Anchovy Sauce, Myeolchi-Aekjeot. LWT - Food Science and Technology. 73:251-258.

Nadiah I, Mohd B, Huda N, Nadiah W, Abdullah W, Al-karkhi AFM. 2014. Protein Quality of Fish Fermented Product: Budu and Rusip. Asia Pacific Journal of Sustainable Agriculture Food and Energy. 2(2):17-22.

Nofiani R, Ardiningsih P. 2018. Physichochemical and Microbiological Profiles of Commercial Cincalok from West Kalimantan. Jurnal Pengolahan Hasil Perikanan Indonesia. 21(2):243249.
Nofiani R, Kalbar M, Ardiningsih P. 2010. Chemical Characteristic and Microbiological Safety of Commercial Fermented Ala-Ale from West Kalimantan, Indonesia. Journal of Fisheries and Aquatic Science. 5(6), 483493.

Northrop BYJH. 1926. A Convenient Method for The Formol Titration. The Journal of General Physiology. 767-769.

Pessione E. 2012. Lactic Acid Bacteria Contribution to Gut Microbiota Complexity: Lights and Shadows. Frontiers in Cellular and Infection Microbiology. 2:1-15.

Rhee S, Lee JE, Lee CH. 2011. Importance of Lactic Acid Bacteria in Asian Fermented Foods. Microbial Cell Factories. 10:S5.

Sedanza MGC, Posadas NG, Serrano Jr AES, Nuñal SN, Pedroso FL, Yoshikawa T. 2016. Development of Aquafeed Ingredient by Solid State Fermentation of the Crinklegrass, Rhizoclonium riparium on a Laboratory Scale. Aqualculture, Aquarium, Conservation, and Legislation. 9(3):733-740.

Wu YY, You G, Li LH. 2015. The Application Status of Microbes in Salted Fish Processing. In T. Zhang \& $\mathrm{M}$. Nakajima (Eds.), Advances in Applied Biotechnology. Berlin (Germany) : Published by Springer-Verlag

Xu Y, Li L, Xia W, Zang J, Gao P. 2019. The Role of Microbes in Free Fatty Acids Release and Oxidation in Fermented Fish Paste. LWT - Food Science and Technology. 101:323-330. 